\begin{tabular}{|cl}
\hline Jurnal Teknologi Kimia Unimal & $\begin{array}{l}\text { Jurnal } \\
\text { Teknologi } \\
\text { Kimia } \\
\text { Unimal }\end{array}$ \\
\hline
\end{tabular}

\title{
Pengomposan limbah lumpur dan serat buah kelapa sawit pada kondisi steril dan tidak steril menggunakan Mikroorganisme Lokal (MOL)
}

\author{
Elvi Yenie ${ }^{1}$, Syarfi Daud ${ }^{2}$ \\ ${ }^{1,2}$ Dosen Teknik Lingkungan \\ Fakultas Teknik Universitas Riau \\ Kampus Bina Widya Jl. HR Soebrantas Km12,5 Simpang Baru, Panam \\ Pekanbaru 28293 \\ e-mail : elviyenie@yahoo.co.id
}

\begin{abstract}
Abstrak
Produksi minyak sawit yang tinggi berbanding lurus dengan produksi limbahnya. Lumpur kelapa sawit merupakan larutan buangan yang dihasilkan selama proses pemerasan dan ekstraksi minyak.Limbah lumpur kelapa sawit disamping sebagai sumber hara makro dan mikro yang penting bagi tanaman, juga sebagai sumber bahan organik dan berperan pada perbaikan sifat fisik dan kima tanah. Limbah padat lainnya yang belum dimanfaatkan secara maksimal adalah serat buah kelapa sawit yang juga mengandung unsur hara. Dari kedua potensi limbah padat kelapa sawit menunjukkan bahwa sangat perlu dilakukan pengolahan khususnya pada limbah lumpur dan serat buah dimana berdasarkan hasil analisa laboratorium mengandung unsur hara yang baik untuk dikonversi menjadi pupuk kompos. Mikroorganisme lokal (MOL) adalah mikroorganisme yang dimanfaatkan sebagai starter atau aktivator dalam pembuatan pupuk organik padat maupun pupuk cair. Bahan utama MOL terdiri dari beberapa komponen yaitu karbohidrat, glukosa, dan sumber mikroorganisme. Tujuan penelitian ini adalah mengetahui kemampuan MOL sebagai aktivator dalam proses pengomposan limbah lumpur dan serat buah kelapa sawit yang disterilkan dan tidak disterilkan. Dari hasil penelitian dapat ditarik kesimpulan bahwa mikroorganisme pada MOL yang berperan sebagai pendegradasi pada proses pengomposan lumpur dan serat buah kelapa sawit. Hal ini berdasarkan hasil analisa proses fermentasi tapai singkong menjadi MOL dimana jumlah mikroorganisme pada hari pertama sebesar 403,45mg/l dan pada hari kelima jumlah mikroba meningkat menjadi $456,10 \mathrm{mg} / \mathrm{l}$. Selain itu dapat dilihat juga bahwa bahan baku yang disterilkan untuk parameter kualitas kompos antara lain : $N, P, K, C, C / N, M g, C a$, temperatur, $p H$, dan kadar air, mempunyai nilai yang mendekati SNI berbanding bahan baku yang tidak steril. Penggunaan MOL sebagai sumber mikroorganisme dalam proses pengomposan dapat dijadikan alternatif sebagai bioaktivator yang ekonomis dan ramah lingkungan.
\end{abstract}

Kata kunci : MOL, lumpur kelapa sawit, pengomposan, aktivator, steril 


\section{Pendahuluan}

Kelapa sawit merupakan salah satu komoditi andalan Indonesia yang perkembangannya demikian pesat. Tanaman kelapa sawit saat ini tersebar di hampir seluruh provinsi di Indonesia. Provinsi Riau pada Tahun 2014 dengan luas areal seluas 2,30 juta Ha merupakan provinsi yang mempunyai perkebunan kelapa sawit terluas disusul berturut-turut Provinsi Sumatera Utara seluas 1,39 juta Ha, Provinsi Kalimantan Tengah seluas 1,16 juta Ha dan Sumatera Selatan dengan luas 1,11 juta Ha serta provinsi-provinsi lainnya (Ditjen Perkebunan, 2014).

Pabrik kelapa sawit berkontribusi paling besar terhadap isu lingkungan oleh akumulasi jumlah limbah cair dan padat [Baharuddin et.al,2009], emisi gas rumah kaca [Reijnder dan Huijbregts,2008] yang berasosiasi dengan deforestasi dan hilangnya keanekaragaman [Wicke et.al,2008].

Produksi minyak sawit yang tinggi berbanding lurus dengan produksi limbahnya.Limbah cair kelapa sawit mengandung bahan organik yang cukup tinggi sehingga berpotensi mencemari air tanah dan badan air. Limbah padat pabrik kelapa sawit berasal dari proses pengolahan berupa tandan kosong kelapa sawit, cangkang atau tempurung, serabut atau serat, dan sludge (lumpur).

Lumpur sawit merupakan larutan buangan yang dihasilkan selama proses pemerasan dan ekstraksi minyak. Kandungan unsur hara yang berasal dari limbah lumpur kelapa sawit sekitar $0,4 \%(\mathrm{~N}), 0,029-0,05 \%\left(\mathrm{P}_{2} \mathrm{O}_{5}\right), 0,15-0,2 \%$ $\left(\mathrm{K}_{2} \mathrm{O}\right)[$ Astianto, 2012].Unsur hara yang terkandung ini dapat meningkatkan sifat fisik-kimia tanah, serta dapat meningkatkan status hara tanah sehingga limbah ini berpotensi untuk diolah dan dijadikan suatu produk yang ramah lingkungan seperti kompos.

Limbah lumpur PKS disamping sebagai sumber hara makro dan mikro yang penting bagi tanaman, juga sebagai sumber bahan organik, berperan pada perbaikan sifat fisik dan kima tanah, antara lain peningkatan Kapasitas Tukar Kation (KTK) dan peningkatan porositas tanah (Siregar, 2007). 
Penggunaan lumpur memberikan pengaruh nyata terhadap tinggi tanaman, diameter batang, jumlah polong tanaman, produksi perplot dan produksi perhektar untuk tanaman (Dartinus, 2007). Menurut Harahap (2007) sludge minyak kelapa sawit berpengaruh nyata terhadap penaikan berat kering akar, berat kering tanaman dan serap kering N, P, K pada tanaman jagung.

Limbah padat lainnya yang belum dimanfaatkan secara maksimal adalah serat buah kelapa sawit. Berdasarkan hasil uji laboratorium menyatakan bahwa serat buah kelapa sawit mengandung unsur hara antara lain $0,320 \% \mathrm{~N}, 0,080 \% \mathrm{P}$, 0,470 \% K, 0,020\% Ca dan 0,110\% Mg [PKS PT. Korindo,2012].

Dari kedua potensi limbah padat kelapa sawit yang ada di pabrik kelapa sawit menunjukkan bahwa sangat perlu dilakukan pengolahan khususnya pada limbah lumpur dan serat buah dimana berdasarkan hasil analisa laboratorium mengandung unsur hara yang baik untuk dikonversi menjadi pupuk kompos.

Kompos adalah hasil penguraian tidak lengkap/parsial dari campuran bahan organik yang dapat dipercepat oleh populasi mikroba secara artifisial dalam kondisi lingkungan yang hangat, lembab, dan aerobik atau anaerobik [Crawford, 2003]. Pengomposan adalah proses degradasi limbah organik yang mengalami perubahan bentuk dan stabil oleh aktivitas metabolisme dari berbagai campuran mikroba [Baharuddin et.al, 2009]. Dekomposisi dari limbah organik selama proses pengomposan dilakukan oleh komunitas mikroba [Hiroaki et.al, 2006] yang menghasilkan enzim.

Pengomposan dapat dipercepat dengan beberapa strategi. Salah satunya adalah menambahkan mikroorganisme yang dapat mempercepat proses pengomposan (aktivator) seperti mikroba, pendegradasi bahan organik dan lainlain.

Saat ini dipasaran banyak sekali beredar aktivator-aktivator pengomposan, misalnya : Promi, OrgaDec, SuperDec, ActiComp, EM4, Stardec, Starbio, dll. Promi, OrgaDec, SuperDec, dan ActiComp. Bioaktivator yang digunakan dalam 
penelitian ini adalah Mikroorganisme Lokal (MOL) berbahan dasar tapai singkong.

Mikroorganisme lokal (MOL) adalah mikroorganisme yang dimanfaatkan sebagai starter atau aktivator dalam pembuatan pupuk organik padat maupun pupuk cair. Bahan utama MOL terdiri dari beberapa komponen yaitu karbohidrat, glukosa, dan sumber mikroorganisme. Bahan dasar untuk fermentasi larutan MOL dapat berasal dari hasil pertanian, perkebunan, maupun limbah organik rumah tangga.

Tujuan penelitian ini adalah mengetahui kemampuan MOL sebagai aktivator dalam proses pengomposan limbah lumpur dan serat buah kelapa sawit yang disterilkan dan tidak disterilkan. Alasan perlakuan steril dan tidak adalah untuk mengetahui mikroorganisme mana yang berperan apakah mikroorganisme yang terdapat dalam limbah lumpur dan serat buah atau mikroorganisme didalam MOL.

Tapai adalah makanan yang terbuat dari singkong yang difermentasi dengan ragi tapai. Mikroba yang terdapat di dalam ragi adalah kapang, actinomycetes, khamir dan bakteri. Bakteri yang sering ditemukan di dalam ragi tape berasal dari genus Pediococcus dan Basillus. Kapang yang berperan adalah Amylomyces, Mucor dan Rhizopus sp. dan khamir yang berperan adalah Endomycopsis fibuliger, Saccharomyces cerevisiae dan Hansenula sp. (Saono et al., 1982).

MOL tapai dibuat dengan mencampurkan tapai singkong dengan air dan gula. Campuran tersebut disimpan didalam botol dan didiamkan sampai lima hari. Setelah lima hari, mikroorganisme lokal (MOL) sudah dapat digunakan. Aplikasia pada bahan yang dikomposkan adalah sebanyak 2,5 liter mol untuk membuat 1 ton kompos (Setiawan, 2010).

\section{Metode Penelitian}

Penelitian dilaksanakan di Laboratorium Pencegahan Pencemaran Jurusan Teknik Kimia Universitas Riau. Bahan yang digunakan adalah lumpur kelapa 
sawit dan serat buah kelapa sawit. MOL tapai, serta bahan-bahan kimia untuk analisis kualitas kompos (N,P,K,Ca,Mg, C/N). Peralatan yang digunakan antara lain : 6 buah komposter (ember yang diberilubang di sekelilingnya dengan diameter $1 \mathrm{~cm}$ dan jarak antar lubang $5 \mathrm{~cm}$ ), sekop kecil, timbangan, sprayer, $\mathrm{pH}$ meter, termometer, autoclav, gelasarloji, labutakar, gelasbeker, pipet ukur, erlenmeyer, oven, furnance, desikator, pemanas, spektrofotometer dan AAS. Komposter tersebut dapat dilihat seperti pada Gambar 1.

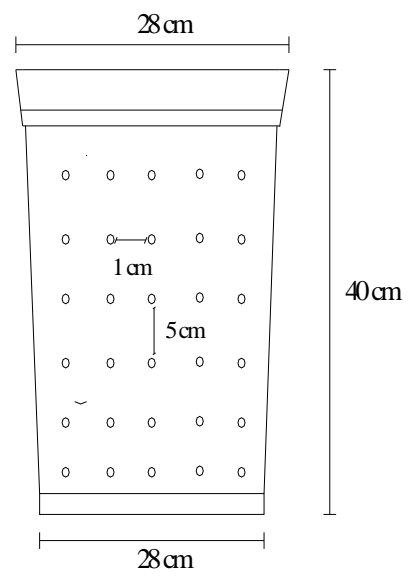

Gambar 1 Komposter

\subsection{Preparasi sampel}

Pengambilan sampel dilakukan di PT Perkebunan Nusantara V (PTPN V) Sei Galuh Kecamatan Tapung, Kabupaten Kampar. Sampel lumpur diambil pada kolam ke-4 yaitu kolam IPAL dan serat buah kelapa sawit berasal dari srew press. Selanjutnya sampel lumpur di jemur selama \pm 5 hari untuk mengurangi kadar air. Sampel lumpur dan serat buah kelapa sawit dilakukan pengujian awal di laboratorum untuk parameter C-Organik, N-total, rasio C/N, P-total, K-total, Magnesium ( $\mathrm{Mg}$ ), Kalsium (Ca), Raksa ( $\mathrm{Hg})$, Kadmium (Cd), Timbal(Pb), Arsen(As), pH, dan kadar air. 


\subsection{Pembuatan MOL tapai}

Tapai singkong sebanyak 1 ons dimasukkan kedalam botol plastik berukuran $1500 \mathrm{ml}$, kemudian ditambahkan airbersih, $\pm 1.000 \mathrm{ml}$ dan gula pasir sebanyak 5 sendokmakan, dikocok sebentar. Selanjutnya difermentasi selama 5 hari dan botol dibiarkan terbuka. Setelah 5 hari MOL dapat digunakan ditandai dengan bau alkohol dan larutan menjadi keruh.

\subsection{Proses pengomposan}

Sepuluh kg lumpur kelapa sawit, $2 \mathrm{~kg}$ serat buah kelapa sawit dengan ukuran partikel 2,36 mm dan sampah pasar sebanyak $2 \mathrm{~kg}$ dimasukkan ke dalam 3 komposter untuk perlakuan tidak disterilkan dan 3 komposter berikutnya disterilkan menggunakan autoclave terlebih dahulu.Ditambahkan larutan mol sebanyak $200 \mathrm{ml}, 250 \mathrm{ml}$ dan $300 \mathrm{ml}$ untuk masing-masing komposter, dilakukan pengadukan agar merata dan ditutup. Suhu dan $\mathrm{pH}$ diukur setiap hari. Pembalikan dilakukan setiap satu minggu sekali (Arumsari, 2012). Selanjutnya pada hari ke21 kompos di panen dan kemudian diukur kandungan unsur hara (C-Organik, Ntotal, rasio C/N, P-total, K-total, Magnesium (Mg), Kalsium(Ca), pH, dan kadar air.

\section{Hasil dan Pembahasan}

\subsection{Uji karakteristik pendahuluan bahan baku kompos}

Tabel 1 Uji pendahuluan sampel

\begin{tabular}{|c|c|c|c|c|c|}
\hline NO & Parameter & Satuan & $\begin{array}{c}\text { Limbah lumpur } \\
\text { kelapa sawit }\end{array}$ & Serat (fiber) & $\begin{array}{c}\text { SNI } \\
19-7030-2004\end{array}$ \\
\hline 1 & Kadar Nitrogen & $\%$ & 1,1 & 2,219 & $>0,4$ \\
\hline 2 & Kadar fosfor $\mathrm{P}_{2} \mathrm{O}_{5}$ & $\%$ & 1,30 & 0,80 & $>0,1$ \\
\hline 3 & Kalium sebagai $\mathrm{K}_{2} \mathrm{O}$ & $\%$ & 0,26 & - & $>0,20$ \\
\hline 4 & Rasio C/N & $\%$ & $7,35^{*}$ & $5,07^{*}$ & $10-20$ \\
\hline 5 & Karbon $(\mathrm{C})$ & $\%$ & $8,16^{*}$ & 11,25 & $9,8-32$ \\
\hline
\end{tabular}




\begin{tabular}{|c|c|c|c|c|c|}
\hline 6 & $\begin{array}{c}\text { Cemaran logam } \\
\text {-raksa }(\mathrm{Hg}) \\
\text { - kadmium }(\mathrm{Cd}) \\
\text { - Timbal }(\mathrm{Pb}) \\
\text { - Arsen }(\mathrm{As})\end{array}$ & $\begin{array}{l}\text { Ppm } \\
\text { ppm } \\
\text { ppm } \\
\text { ppm }\end{array}$ & $\begin{array}{l}<0,012 * *) \\
<0,007 * *) \\
\left.<0,098^{* *}\right) \\
<0,006 * *)\end{array}$ & $\begin{array}{l}- \\
- \\
- \\
-\end{array}$ & $\begin{array}{c}<0,8 \mathrm{mg} / \mathrm{kg} \\
\quad<3 \mathrm{mg} / \mathrm{kg} \\
<150 \mathrm{mg} / \mathrm{kg} \\
<13 \mathrm{mg} / \mathrm{kg}\end{array}$ \\
\hline 7 & Magnesium (Mg) & $\%$ & 14,51 & 0,061 & $<0,6$ \\
\hline 8 & Kalsium $(\mathrm{Ca})$ & $\%$ & 0,93 & 0,323 & $<25,5$ \\
\hline 9 & $\mathrm{pH}$ & - & 5,23 & $6,5^{*}$ & $6,8-7,49$ \\
\hline 10 & Kadar air & $\%$ & 30,72 & 12,81 & $<50$ \\
\hline 11 & Temperatur & ${ }^{0} \mathrm{C}$ & 25,33 & 26,00 & Suhu air tanah \\
\hline
\end{tabular}

Uji karakteristik bahan baku kompos pada beberapa sampel yang akan digunakan dalam penelitian. Hasil uji tersebut akan dijelaskan pada Tabel .1 Dari hasil pengujian awal sampel dapat dijelaskan bahwa unsur karbon yang terkandung dalam lumpur sawit kecil yaitu sebesar $8,16 \%$ sedangkan pada serat fiber $11,25 \%$. Untuk mendapatkan hasil kompos dengan kualitas SNI kompos 197030-2004 perlu penambahan sumber karbon dari sampah organik pasar. Peningkatan karbon pada proses pengomposan dapat dilakukan dengan penambahan sampah pasar karena kandungan karbon pada sampah pasar cukup tinggi mencapai 37,25\% (Hidayati, 2012).

Pengujian sampel juga dilakukan untuk parameter cemaran logam berat. Dari hasil pengujian didapatkan bahwa nilai logam berat yang diuji berada dibawah ambang batas. Dapat disimpulkan bahwa limbah lumpur kelapa sawit aman untuk digunakan sebagai bahan baku kompos.

\subsection{Pengujian jumlah mikroba dalam MOL}


Selama proses pembuatan MOL berlangsung dilakukan pembiakan terhadap jumlah mikroba yang berkembang pada hari ke-1 dan hari ke5.Prinsippengukuran VSS dilakukandenganmetodegravimetric untuk melihat pertumbuhan jumlah mikroba.Pada hari pertama jumlah mikroba yang terdapat didalam MOL tapai sebesar 403,45mg/l dan pada hari kelima jumlah mikroba meningkat menjadi 456,10 mg/l. Dapat disimpulkan bahwa berdasarkan hasil analisa proses fermentasi tapai singkong menjadi MOL dapat digunakan sebagai aktivator dengan adanya peningkatan jumlah mikroba.

\subsection{Hasil analisa kualitas kompos}

Tabel 2 Hasil analisa kualitas kompos

\begin{tabular}{|c|c|c|c|c|c|}
\hline NO & Parameter & Satuan & $\begin{array}{c}\text { Kualitas } \\
\text { Kompos bahan } \\
\text { baku steril } \\
\text { dengan Mol } \\
250 \mathrm{ml}\end{array}$ & $\begin{array}{c}\text { Kualitas } \\
\text { Kompos bahan } \\
\text { baku tidak } \\
\text { steril dengan } \\
\text { Mol 250 ml }\end{array}$ & $\begin{array}{c}\text { SNI } \\
19-7030-2004\end{array}$ \\
\hline 1 & Kadar Nitrogen & $\%$ & 0,79 & 0,67 & $>0,4$ \\
\hline 2 & Kadar fosfor $\mathrm{P}_{2} \mathrm{O}_{5}$ & $\%$ & 1,30 & 0,96 & $>0,1$ \\
\hline 3 & Kalium sebagai $\mathrm{K}_{2} \mathrm{O}$ & $\%$ & 0,26 & 0,3 & $>0,20$ \\
\hline 4 & Rasio C/N & $\%$ & 11,35 & 10,67 & $10-20$ \\
\hline 5 & Karbon $(\mathrm{C})$ & $\%$ & 11,67 & 9,82 & $9,8-32$ \\
\hline 6 & Magnesium $(\mathrm{Mg})$ & $\%$ & 0,32 & 0,45 & $<0,6$ \\
\hline 7 & Kalsium $(\mathrm{Ca})$ & $\%$ & 14,51 & 12,43 & $<25,5$ \\
\hline 8 & Temperatur & ${ }^{0} \mathrm{C}$ & 26,00 & 27,00 & Suhu air tanah \\
\hline 9 & pH & - & 7,5 & 7,4 & $6,8-7,49$ \\
\hline 10 & Kadar air & $\%$ & 40,5 & 39,45 & $<50$ \\
\hline
\end{tabular}

Data hasil analisa kualitas kompos berdasarkan beberapa parameter uji disajikan dalam Tabel 2. Berdasarkan tabel tersebut, parameter kualitas yang diukur dan dibandingkan dengan SNI kompos 19-7030-2004 dapat ditarik kesimpulan bahwa mikroorganisme pada MOL yang berperan sebagai 
pendegradasi pada proses pengomposan lumpur dan serat buah kelapa sawit. Hal ini dapat dilihat bahwa bahan baku yang disterilkan mempunyai nilai yang mendekati SNI berbanding bahan baku yang tidak steril. Hal ini sesuai dengan penelitian Suswardany (2006), yang menyatakan bahwa aktivator Mol tapai bukan merupakan penambah unsur hara (secara langsung) pada kompos tetapi aktivator tersebut merupakan kultur yang didominasi oleh mikroorganisme. Jika MOL ditambahkan dalam bahan baku maka mikroorganisme tersebut akan cepat bereaksi dan menguraikan bahan baku.

\section{Kesimpulan}

1. Mikro organisme pada MOL yang berperan sebagai pendegradasi pada proses pengomposan lumpur dan serat buah kelapa sawit. Hal ini berdasarkan hasil analisa proses fermentasi tapai singkong menjadi MOL di mana jumlah mikroorganisme pada hari pertama sebesar 403,45mg/l dan pada hari kelima jumlah mikroba meningkat menjadi 456,10 mg/l.

2. Bahan baku yang disterilkan untuk parameter kualitas kompos antara lain: $\mathrm{N}, \mathrm{P}, \mathrm{K}, \mathrm{C}, \mathrm{C} / \mathrm{N}, \mathrm{Mg}, \mathrm{Ca}$, temperatur, $\mathrm{pH}$, dan kadar air, mempunyai nilai yang mendekati SNI berbanding bahan baku yang tidak steril.

3. Penggunaan MOL sebagai sumber mikroorganisme dalam proses pengomposan dapat dijadikan alternatif sebagai bioaktivator yang ekonomis dan ramah lingkungan.

\section{Daftar Pustaka}

Arumsari, A. 2012. Pemanfaatan Sludge Hasil Pengolahan Limbah Cair PT. Indofood CBPdengan Penambahan Sampah Domestik Serta Effective Microorganism (EM-4) dan Lumpur Aktif Sebagai Aktivator Melalui Proses Pengomposan. Universitas Diponegoro.Semarang.

Astianto, A., 2012. Pemberian Berbagai Dosis Abu Boiler Pada Pembibitan Kelapa Sawit (Elaeis guineensis Jacq.) di Pembibitan Utama (Pre Nursery). Fakultas Pertanian Universitas Riau, Riau.

Baharuddin A.S., Wakikasa M., Shirai Y., Abd-AzisS., Abdul Rahman N.A., and Hassan M.A. (2009) Cocompostingof Empty Fruit Bunches and 
Partially Treatedpalm Oil Mill Effluent in Pilot Scale. Int. J. of Agri.Research 4(2), 69-78. 2009.

Crawford. J.H. . Composting of Agricultural Waste. in Biotechnology Applications and Research, Paul N, Cheremisinoff and R. P.Ouellette (ed). p. 68-77. Dartius, 1990.Pengaruh limbah padat (sludge) kelapa sawit terhadap pertumbuhan dan produksi kacang hijau.USU. Medan.

Dinas Perkebunan Provinsi Riau. 2014. Produktivitas Lahan Kelapa Sawit dan Kapasitas PKSDaerah Riau.

Epstein,E.,(1997). Soil imvroves and growing media. Science direct.

Harahap,A.S.,1992. Pengaruh pemberian lumpur minyak sawit kering dan tepung tulang terhadap serapan hara N,P,K oleh tanaman jagung pada Ultisol Tambunan A. Fakultas pertanian. USU. Medan.

Hemiwati.2012.Karakteristik Mikroorganisme Lokal Sebagai Biodekomposer Pada Pengomposan Bahan Organik.Prosiding. Sulawasi Utara.

Hukimuddin,S.2005. Pengujian limbah padat kelapa sawit (sludge) kelapa sawit terhadap pertumbuhan dan produksi varietas kacang hijau. Unversitas Sumatra Utara,Medan.

Hutagalung, R dan Jalaluddin. 1982. Feeds for Farm Animal from The Oil Palm. Dept. of Animal Science University. Serdang.

Jenderal, S. (2007). Gambaran Sekilas Industri Kelapa Sawit. Jakarta: Departemen Perindustrian.

Loebis, B. Dan P. LTobing. 2006. Potensi Pemanfaatan Limbah Pabrik Kelapa Sawit. Buletin Perkebunan BPP Medan. Volume 19 No. 20 : 49-56. Medan.

Mulyono. 2014. Membuat Mol Dan Kompos Dari Sampah Rumah Tangga. Agromedia pustaka. Jakarta.

Priyambada,G. 2015. Studi Pemanfaatan Lumpur, Abu Boiler, Serat (Fiber) Kelapa Sawit Sebagai Kompos Menggunakan Variasi Effective Microorganism (Em-4).Fakultas Teknik.Universitas Riau.Pekanbaru.

Purwanasasmita dan Kurnia, 2009. Mikroorganisme Lokal Sebagai Pemicu Siklus Kehidupan Dalam Bioreaktor Tanaman. Makalah Seminar Teknik Kimia ITB 19-20 Oktober 2009, Bandung. 
Ristiawan A. 2012. Studi Pemanfaatan Aktivator Lumpur Aktif dan EM4 Dalam Proses Pengomposan Lumpur Organik, Sampah Organik Domestik, Limbah Bawang Merah Goreng Dan Limbah Kulit Bawang. Universitas Diponegoro.Semarang.

Saono, S., R.R. Hull \& B. Dhamcharee. 1986 A Concise Handbook of Indigenous Fermented Foods in the ASCA Countries. Indonesian Institute of Sciences, Jakarta, Indonesia.

Setyorini, Diah., Rasti, S., Ea Kosman, A, 2006, Kompos, Pupuk Organik dan Pupuk Hayati, Jurnal Balai Besar Litbang Sumber Daya Pertanian, 11-40, Bogor.

Sitanggang, K. 2011. Pembuatan Tablet Kompos N, P, K, Dari Kompos Tandan Kosong Kelapa Sawit dan Kulit Buah Kakao. Fakultas Matematika dan Ilmu Pengetahuan Alam. Universitas Sumatera Utara. Medan.

Suyanto Dkk.2015 Efektivitas Trichoderma Sp Dan Mikro Organisme Lokal (Mol) Sebagai Dekomposer Dalam Meningkatkan Kualitas Pupuk Organik Alami Dari Beberapa Limbah Tanaman Pertanian. Jurnal Agrosains Vol 12 NO 2 2015. ISSN: 1693-5225.

Royaeni Dkk.2014. Pengaruh Penggunaan Bioaktivator Mol Nasi Dan Mol Tapai Terhadap Lama Waktu Pengomposan Sampah Organik Pada Tingkat Rumah Tangga. Jurusan Kesehatan Lingkungan, Poltekkes Bandung. 